\title{
Inositol Hexakisphosphate Kinase 1
}

National Cancer Institute

\section{Source}

National Cancer Institute. Inositol Hexakisphosphate Kinase 1. NCI Thesaurus. Code C125102.

Inositol hexakisphosphate kinase 1 (441 aa, $~ 50 \mathrm{kDa}$ ) is encoded by the human IP6K1 gene. This protein is involved in the metabolism of second messenger molecules. 